\title{
Hydrological Characteristics of Ordovician Karst Top in a Deep Region and Evaluation of Its Threat to Coal Mining: A Case Study for the Weibei Coalfield in Shaanxi Province, China
}

\author{
Tao Li $\mathbb{D},{ }^{1,2,3}$ Jiarui Zhang $\mathbb{D}^{2},{ }^{2}$ Ying Gao $\mathbb{D}^{1},{ }^{1}$ Xinqi Cao $\mathbb{D},{ }^{4}$ Hongyang Liu $\mathbb{D},{ }^{1}$ Peng Zhang $\mathbb{D}^{1}$ \\ and Junwei Yang ${ }^{1}$ \\ ${ }^{1}$ School of Mining \& Civil Engineering, Liupanshui Normal University, Liupanshui 553000, China \\ ${ }^{2}$ School of Geology and Environment, Xi'an University of Science and Technology, Xi'an 710000, China \\ ${ }^{3}$ Key Laboratory of Mine Geological Hazards Mechanism and Control, Shaanxi Institute of Geological Survey, Xi'an 710065, China \\ ${ }^{4}$ Hancheng Mining Industry Co., Ltd., Hancheng 715400, China
}

Correspondence should be addressed to Tao Li; qazwdx521@163.com

Received 19 December 2019; Revised 25 June 2020; Accepted 31 July 2020; Published 25 August 2020

Academic Editor: Micòl Mastrocicco Copyright (c) 2020 Tao Li et al. This is an open access article distributed under the Creative Commons Attribution License, which
permits unrestricted use, distribution, and reproduction in any medium, provided the original work is properly cited.

\begin{abstract}
Widely distributed in North China, Ordovician karst is characterized by having high thickness, nonuniform aquosity, and significant water pressure-bearing properties. Deep mining in North China is threatened by associated water hazards; hence, research on the hydrogeological characteristics of deep Ordovician karst is needed. In this study, the Weibei coalfield in Shaanxi Province, China, was selected as the study area, especially mines in the Hancheng and Chenghe mining areas. In situ experiments, including water pumping, water drainage, water injecting and water pressure, and laboratory experiments, were conducted to study the hydrogeological characteristics of the Ordovician karst top in the study area. A comprehensive analysis was conducted on controlling factors for the development of the Ordovician karst top in the study area, and a method for evaluating the water inrush risk in coal mining areas based on karst hydrogeological characteristics was proposed. The research results indicated that the Ordovician karst top in the study area was characterized by heterogeneity, vertical zonation, and partially filled properties, which were mainly controlled by two factors: sedimentation and tectonism. The hydrogeological conditions of the Ordovician karst could be divided into three types: nonfilled and nonsignificant tectonism, filled and nonsignificant tectonism, and significant tectonism. Among them, the filled and nonsignificant tectonism type Ordovician karst top type had a filling thickness of $20 \mathrm{~m}$. Based on karst hydrogeological characteristics, the methods were proposed to evaluate the water inrush risk in the coal mining floor. The practical tests verified the methods.
\end{abstract}

\section{Introduction}

North China is rich in coal resources, but coal mining is threatened by underlying confined water due to huge water-bearing karst systems under coal seams [1-3]. In particular, with the deep extension of coal mining in North China, the aquiclude between coal seams and karst aquifers becomes progressively thinner, causing more water inrush accidents occurring in the karst aquifer in coal mines [4-6]. Therefore, it is of great theoretical and practical significance to evaluate the threat of karst aquifers to coal mining.
It is very difficult to study the hydrological characteristics of deep karst, although there have been abundant relevant studies [7]. The main research methods include geophysical exploration, hydrogeochemical exploration, drilling engineering, and supporting hydrological experiments [8-13]. In particular, abundant hydrogeological information can be obtained by carrying out in situ hydrological tests inside boreholes, so this is considered to be a primary method for studying karst hydrogeological characteristics in deep strata [14]. Through exploration by various means, a large number of researchers have found that in Ordovician karst tops in 
North China, there generally exists a relatively waterproof filling zone, which can be a favorable geological condition for mining above the confined coal seam water body (Ordovician karst water) [15]. However, the development characteristics and controlling factors of the filling zone are unclear, and there is still no systematic study evaluating the floor water inrush risk during mining under pressure [15-17].

Therefore, many experts and engineers have carried out research on the threat of karst aquifer to coal mining [1820]. The research methods include the GIS evaluation method, numerical simulation evaluation method, and water inrush coefficient theory evaluation method. First, due to the diversity of factors affecting water inrush, the GIS evaluation method has attracted researchers' attention. Based on the GIS system, Wu et al. [21-24] had proposed several vulnerability methods to evaluate the water inrush with coal mining. Vulnerability assessments have been successfully applied worldwide, which can integrate multiple factors and assign a weight to each factor according to its importance [25-27]. Based on the GIS system, Chen et al. [28] used three methods to evaluate the water resources in the coal mine area. Zhao used the random forest method to predict the risk of water inrush in the Panjiayao coal mine [29]. Second, the numerical simulation technology is more effective for the water inrush evaluation of a single coal mining face, so there are a large number of experts carrying out research using numerical simulation. Lu and Wang evaluated the influence of confined aquifer on coal mining by numerical simulation [30]. Zhang et al. studied the evolution of water inrush from the floor under fault condition by numerical simulation [31]. Yin et al. simulated the water seepage of deep mining in China [32]. Yao et al. established a numerical model to simulate the water inrush in the Wuyang coal mine [33]. Third, engineers prefer to use the simple water inrush coefficient method, although the accuracy of this method is slightly poorer [34]. In order to improve the accuracy of the water inrush coefficient, many experts had made further research on mining geology and hydrogeology. Wu et al., combining the theory of the water inrush coefficient, proposed the "three maps two predictions" method [35]. The theory of the water inrush coefficient had been further optimized by Qiao et al. in combination with the waterbearing coefficient, and the accuracy was improved [36].

In this paper, due to the different types of karst in deep strata, various hydrological tests inside boreholes were conducted on the ground and under the coal mine, including water pressure, water pumping, water injecting, and water drainage experiments. These results along with inlaboratory dissolution experiments were used to study the hydrogeological characteristics of Ordovician karst in deep strata. In combination with the water inrush coefficient theory, the threat of karst water to coal mining was evaluated. The above studies provide key geological information for mining coal above karst confined water.

\section{Study Area}

2.1. Scope of Study Area. The Weibei coalfield is located in the middle of Shaanxi Province, China, and north of Weihe River, including several mining areas: Tongchuan, Pubai,
Chenghe, and Hancheng (as shown in Figure 1). The Ordovician strata in the Weibei coalfield are all composed of karst. With respect to burial conditions, Tongchuan and Pubai mining areas are shallow recharge areas while Chenghe and Hancheng mining areas are deep, and the burial depth of karst is generally greater than $600 \mathrm{~m}$. In this study, Chenghe and Hancheng mining areas were selected as the study areas, and the karst top hydrological characteristics in the study area were the study objects.

2.2. Hydrogeological Conditions. The main strata from new to old in the study area were the Cenozoic unconsolidated stratum, upper Permian stratum, lower Permian stratum, upper Carboniferous stratum, middle Carboniferous stratum, middle Ordovician stratum, and lower Ordovician stratum. In this study, the main study objects (from top to bottom: coal seam-aquiclude-karst water-bearing stratum) had the following geological characteristics:

(1) Coal seam: upper Carboniferous strata mainly consisted of minable coal seams labeled 2\#, 3\#, 5\#, 10\#, and 11\#. Among them, coal seam 5\# (with a thickness of 3-4 $\mathrm{m}$ ) in the Chenghe mining area and coal seam 11 \# (with a thickness of 2-5 m) were the most deeply located in minable coal seams in their corresponding areas. Because they are the most threatened by the underlying Ordovician karst confined water, the two seams were selected for evaluation

(2) Aquiclude: there was high stratigraphic incompleteness between the target coal seams to be evaluated and the water-bearing karst stratum. In its forming period, the whole of North China was uplifted and suffered weathering and denudation. Therefore, aquiclude thickness mainly ranged from 15 to $30 \mathrm{~m}$, the smallest in North China [37]. The aquiclude also underwent many tectonic changes with different properties, modes, and directions, generating destruction on different scales

(3) Karst aquifer: from new to old, the middle Ordovician karst strata consisted of Section 2 of the Fengfeng Formation, Section 1 of the Fengfeng Formation, Section 2 of the Upper Majiagou Formation, Section 1 of the Upper Majiagou Formation, Section 2 of the Lower Majiagou Formation, and Section 1 of the Lower Majiagou Formation. The Chenghe mining area suffers less weathering and denudation. The latest stratum of the middle Ordovician was Section 2 of the Fengfeng Formation, which was composed of medium-thick bedded pure limestone with an average thickness of $160 \mathrm{~m}$, and the water pressure on the aquiclude was 0.6-3 $\mathrm{MPa}$. The Hancheng mining area suffered more weathering and denudation. The latest stratum of the middle Ordovician was Section 1 of the Fengfeng Formation, which was composed of argillaceous limestone and argillaceous dolomite. The number of argillaceous layers accounted for over $55 \%$, the average thickness was $100 \mathrm{~m}$, and the water pressure acting on the aquiclude was $0.5-2.8 \mathrm{MPa}$ 


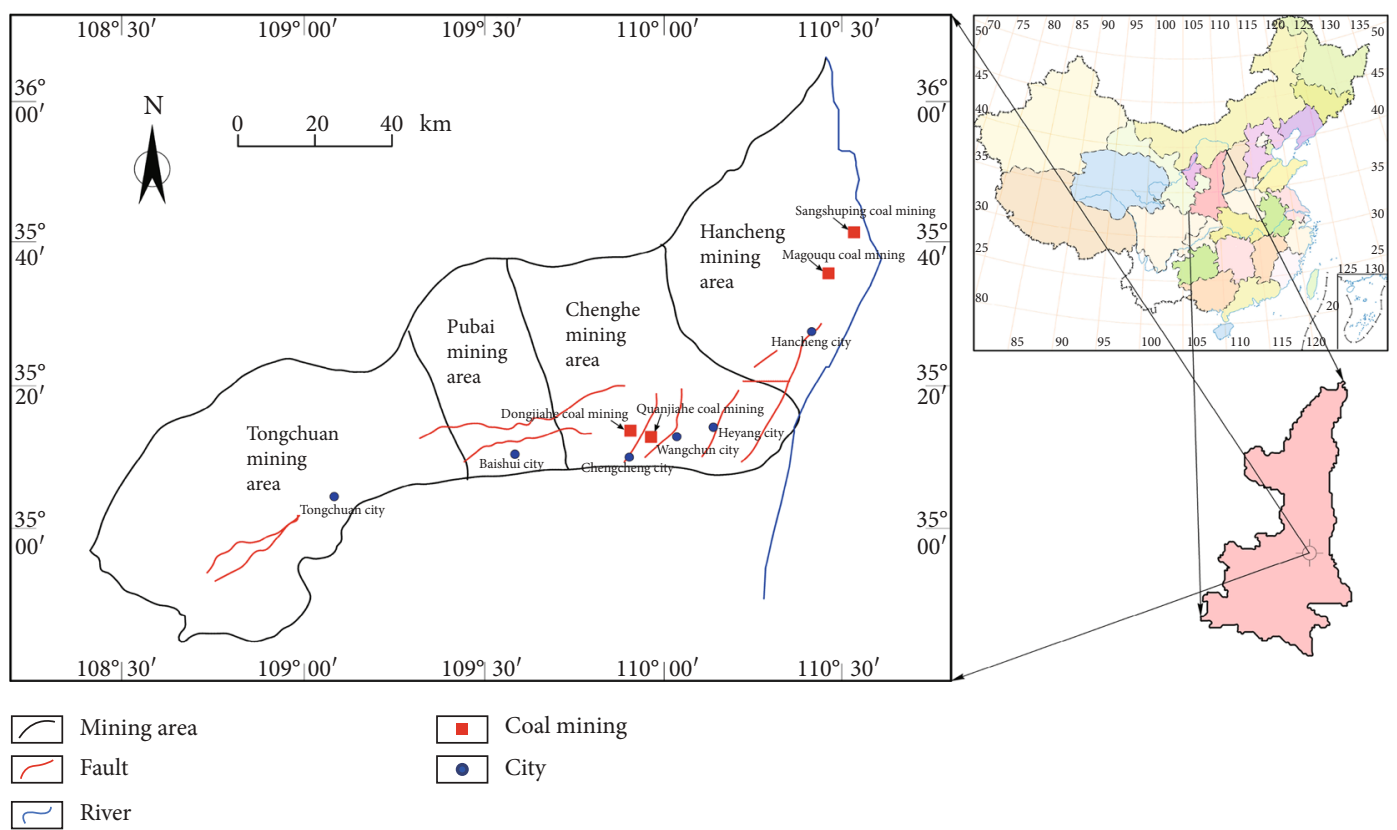

FIGURE 1: Boundary of research area.

2.3. Water Inrush Hazard to Coal Mining in the Study Area. As shown in Figure 2, the floor rock stratum has been damaged by coal mining stress and the remaining aquiclude cannot bear the hydrostatic pressure of karst confined water, leading to water inrush. Such water inrush is more likely to happen in areas with developed structure. In the two studied mining areas, water inrush phenomena at different scales occurred more than 20 times. Water inrush accidents occurred the most in the Chenghe mining area, accounting for $92 \%$, with water inflow generally exceeding $1000 \mathrm{~m}^{3} / \mathrm{h}$ each time. In the Hancheng mining area, water inrush accidents occurred less often and many signs of tectonic development have been traced in the areas where water inrush occurred, such as fault development and column collapse. There is a remarkable divergence in water inrush accidents between the two mining areas with similar conditions, so it is necessary to perform comparative testing on the waterbearing karst stratum. Therefore, a series of borehole hydrological experiments and sampling tests were carried out.

\section{Methods}

3.1. Route of Technical Study. The study route is shown in Figure 3. Studies evaluating the water inrush risk of deep karst in coal mining areas involve two aspects. The first is to study deep karst top hydrogeological characteristics and the corresponding controlling factors, and the second is to study how to evaluate water inrush risk under different karst hydrogeological types. The hydrogeological characteristics of karst form the research foundation, and classified risk evaluation for water inrush makes up the engineering application.

In terms of karst hydrogeological characteristics, corresponding hydrological in situ tests were first carried out according to different borehole exposure conditions, with the specific research schemes shown in Figure 3(a). Then, by sampling, a laboratory dissolution experiment was carried out, with the specific experimental study schemes shown in Figure 3(b). Lastly, in situ and laboratory experiments were combined to analyze the factors controlling karst development in Ordovician karst top, with the specific research schemes shown in Figure 3(c). Based on classification of Ordovician karst top development trends, methods for evaluating water inrush risk in mining under pressure were studied and practiced, with the specific schemes shown in Figure 3(d).

3.2. Classification of In Situ Test Methods. To investigate the hydrological characteristics of Ordovician karst top in the study area, four in situ test methods were used: water pumping, water drainage, water injecting, and water pressure experiments. The four test methods had the following applicable conditions and functions (shown in Figure 4):

(1) In situ water pumping experiment: the water pumping experiment was mainly applied where there was a large amount of water in karst strata, which was the test conducted in surface boreholes. Because the karst strata water level was below ground level, the hydrological characteristics could only be studied by pumping. Because the karst strata contained water, it usually had better recharge conditions and it was difficult to cause a huge drop in water level through pumping. Therefore, pumping reflected the hydrogeological characteristics in small-ranged karst strata.

(2) In situ water drainage experiment: the water drainage experiment was also applicable when there was a large amount of water in karst strata but was conducted in the borehole under the coal mine. Because the karst stratum water level was higher than the 


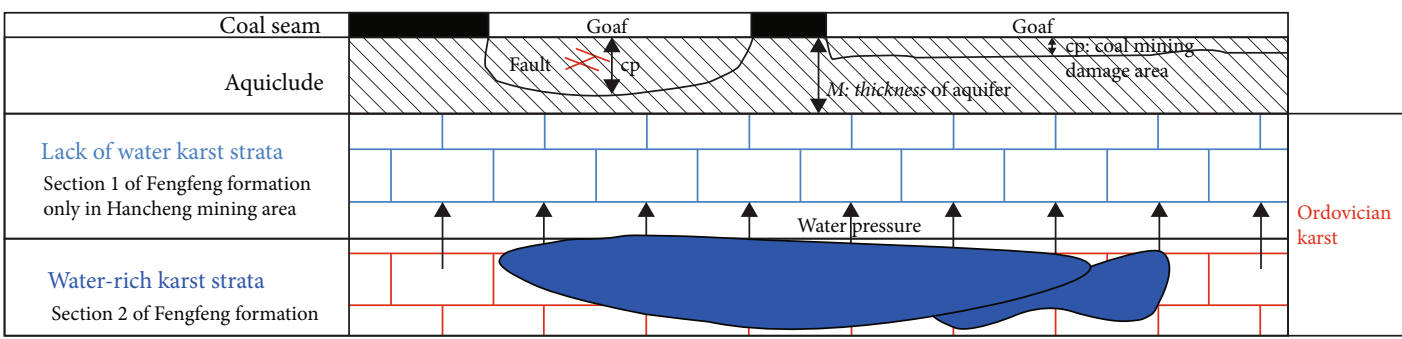

FIgURE 2: Schematic diagram of water inrush from coal mining floor.

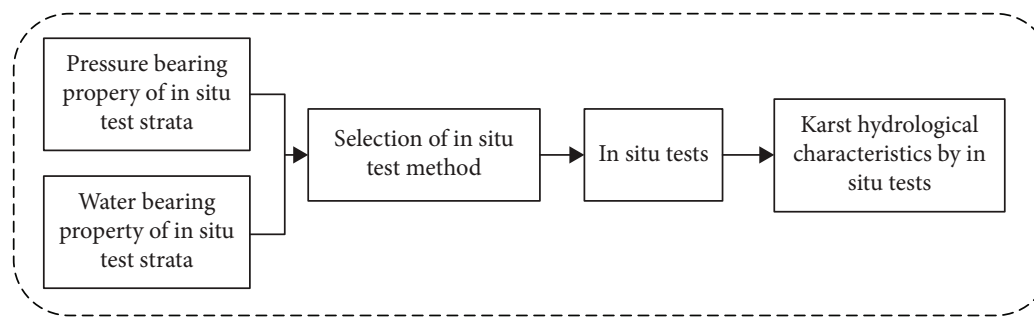

(a)

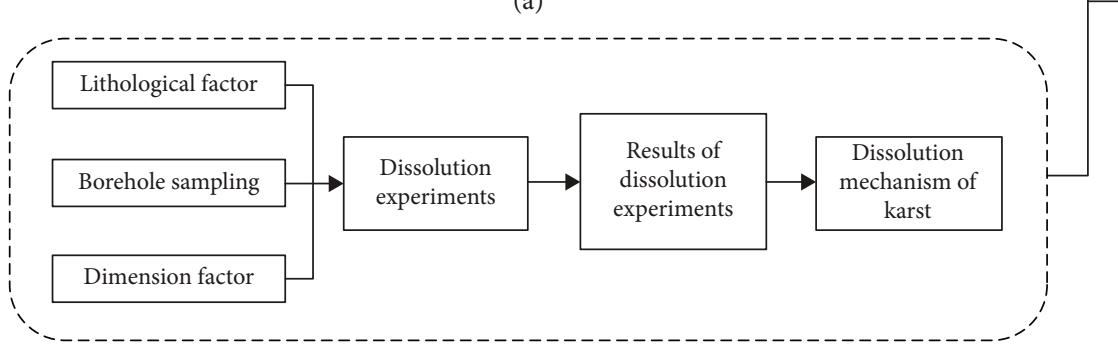

(b)

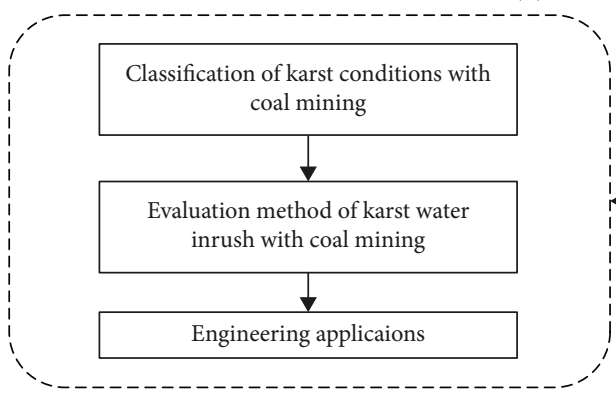

(d)

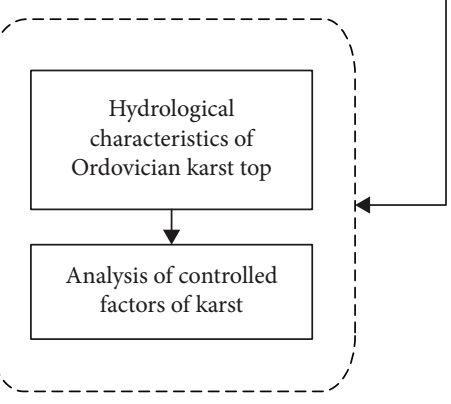

(c)

FIgURE 3: The study route of this paper.

elevation under the coal mine, the hydrological characteristics of karst strata could be studied by draining off water without using a water pump. Because no water pump was involved, according to the Bernoulli equation, all water pressure energy could be transformed into water kinetic energy, and draining water caused a large drop in water level. Therefore, the water drainage experiment reflected the hydrological characteristics in large-ranged karst strata.

(3) In situ water injecting experiment: the water injecting experiment was mainly applicable where there was little water in karst strata and could be conducted in the ground-level boreholes or under drill wells. There was no water in karst strata, but cracks and karst caves may have been present so the experiment was needed. The water injecting experiment was usually carried out using conventional borehole segmentation under low hydrostatic pressure, and the range of water seepage was limited. Therefore, the water injecting experiment reflected the hydrological characteristics in small-ranged karst strata.

(4) In situ water pressurizing experiment: the water pressurizing experiment was mainly applicable when there was little water in karst strata, which could be conducted in the surface boreholes or boreholes under coal mines. There was no water in karst strata, but there may have been cracks and karst caves. Therefore, a hydrological experiment was needed. 


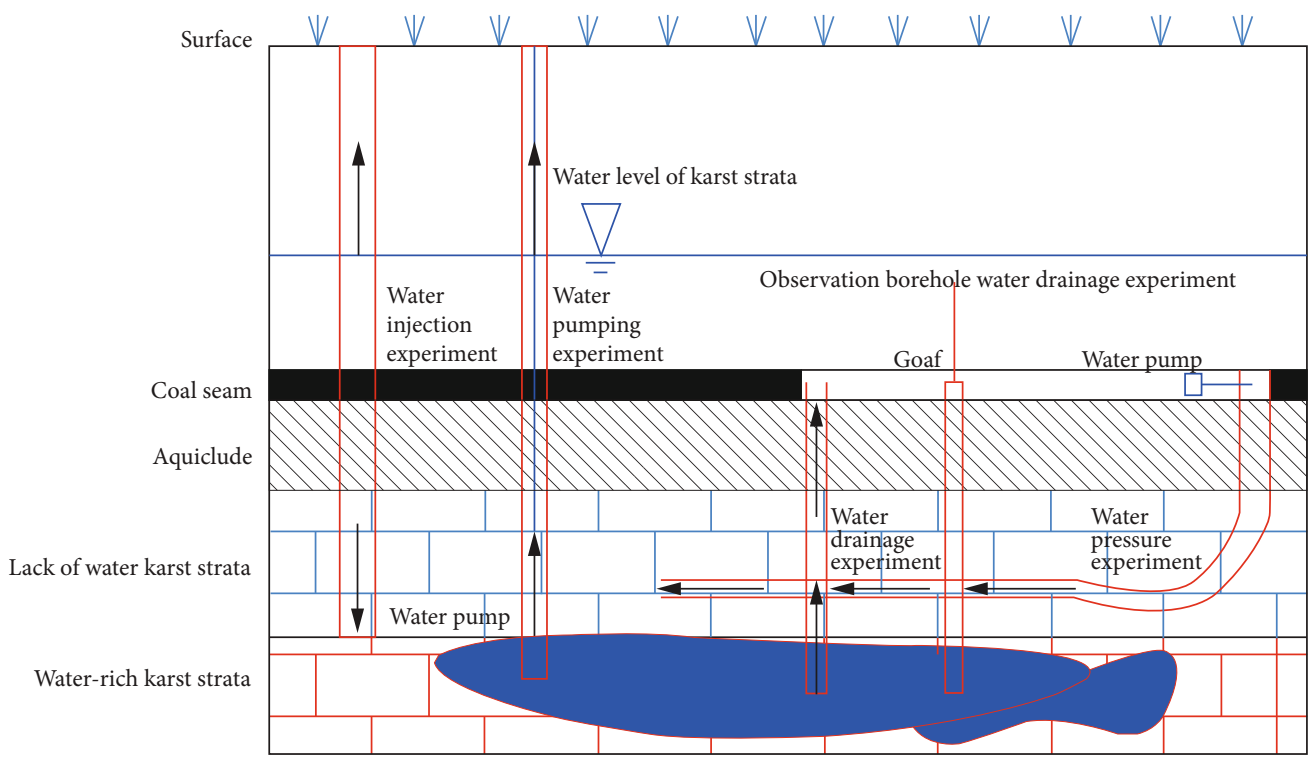

FIgure 4: Schematic diagram of four kinds of hydrological in situ experiments.

The water pressurizing experiment was usually carried out through directional borehole segments under high hydrostatic pressure, which could be used to test the hydrological characteristics in largerranged karst strata.

\subsection{In Situ Test Method}

3.3.1. Water Pumping Experiment. The water pumping experiment was carried out in the Dongjiahe coal mine in the Chenghe mining area (as shown in Figure 1), and the steady-flow pumping experiment on a single-hole completely penetrating well was carried out on a total of eight boreholes: $\mathrm{A} 1, \mathrm{~S}, \mathrm{H} 3, \mathrm{H} 4, \mathrm{H} 5, \mathrm{H} 6, \mathrm{H} 7$, and $\mathrm{H} 8$. The stratum location for the water pumping experiment was Section 2 of the Fengfeng Formation. The steps were as follows: (1) drill vertical downward borehole on the ground surface, with a diameter $\phi$ of $300 \mathrm{~mm}$ and a deflection $\leq 3^{\circ}$; (2) drill to $15 \mathrm{~m}$ below $5 \#$ coal seam, set casing with a diameter of $\phi=245 \mathrm{~mm}$, and shut off water from the above aquifer; (3) maintaining the borehole diameter range of $91-168 \mathrm{~mm}$, drill borehole to $0-5 \mathrm{~m}$ below the bottom floor of Section 2 of the Fengfeng Formation and apply concrete to seal the stratum positions below the bottom floor; and (4)after flushing the well, pump water at three different constant flowrates, including Q1, Q2, and Q3, and observe the hydrological changes in the borehole.

3.3.2. Water Drainage Experiment. The water drainage experiment was carried out in the Quanjiahe coal mine in the Chenghe mining area (as shown in Figure 1), and 10 vertical downward boreholes were drilled in total. Four were drainage holes $(\mathrm{H} 1, \mathrm{H} 2, \mathrm{H} 3$, and $\mathrm{H} 4)$, which were concentrated in the same drilling site (Figure 5), and six were observation holes (G1, G2, G3, G4, G5, and G6), which were dispersed at different positions (Figure 5). All borehole drilling was carried out under the coal mine, and drilling was stopped before reaching Section 2 of the Fengfeng Forma- tion. On the strata above Section 2, casing pipes for stopping water were embedded, and filter tubes were embedded in Section 2.

(1) Before the water drainage experiment was carried out, water samples from six observation holes were obtained, and a simple analysis on water quality was conducted

(2) In the first stage of the water drainage experiment, all water draining holes were opened to the maximum flowrate and drain water off for 1 day. The observed maximum drainage intensity was $1145 \mathrm{~m}^{3} / \mathrm{h}$. Then, the drainage-hole valve was shut for 2 days, allowing the water level in all boreholes to recover to the natural water level

(3) In the second stage of water drainage experiment, four water draining holes were opened simultaneously, with the total water drainage volume set to $1000 \mathrm{~m}^{3} /$ h. After 6-day water drainage, the water levels in all observation holes stabilized. Then, all the water drainage holes were shut at the same time, and the water level in the observation holes was observed. The total observation time for the water level recovery stage was four days

3.3.3. Water Injecting Experiment. The water injecting experiment was carried out in the Magouqu coal mine in the Hancheng mining area (as shown in Figure 1), and in total, 15 vertical downward boreholes were drilled. Borehole drilling stopped at the bottom interface of Section 1 of the Fengfeng Formation, and after drilling was completed, well flushing was carried out to keep the boreholes clean.

The water injecting experiment was divided into four sections. The first section was from the bottom floor of 11 \# coal seam to the Ordovician karst top, the second was within $20 \mathrm{~m}$ below the upper interface of the Ordovician karst, the third 


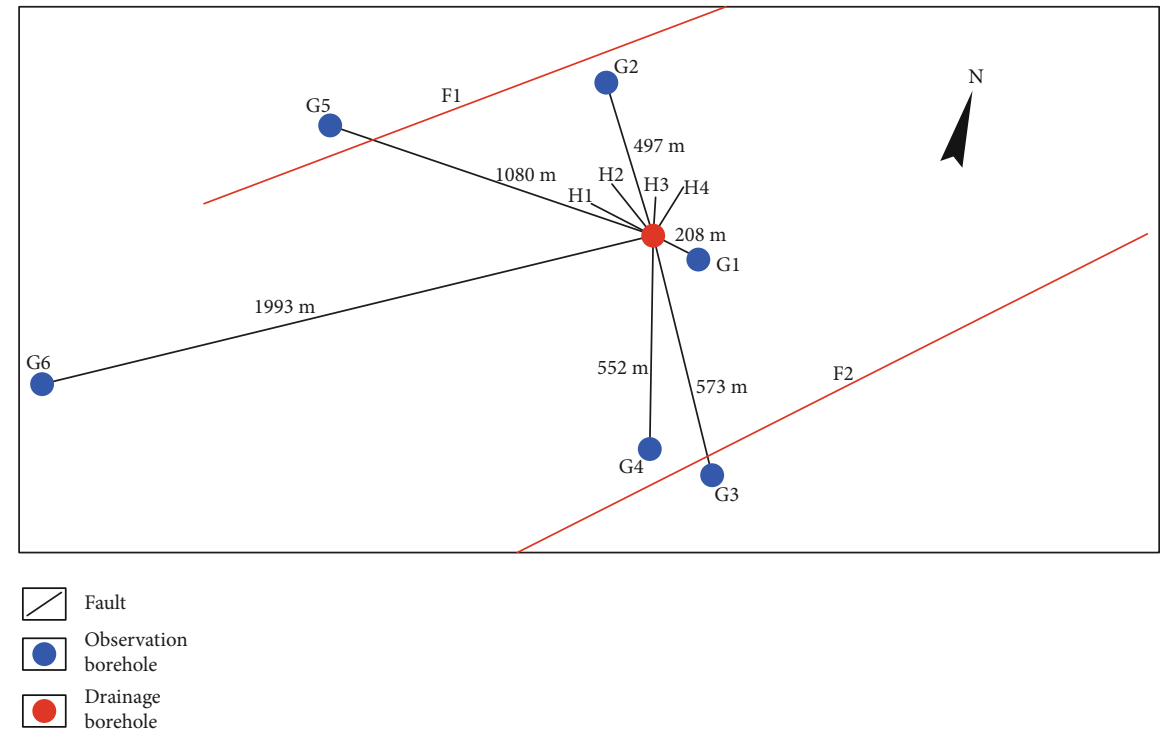

FIGURE 5: Plane figure of water drainage experiment.

was within $30 \mathrm{~m}$ below the bottom of the second section, and the fourth was from the bottom of the third section to the bottom of the borehole. When each section was carried out, a packer was used to separate other water injecting sections for conducting tests.

In water injecting experiment, the water injection level of each section was $10 \mathrm{~m}$ higher than the top surface. The water level was kept stable for $3 \mathrm{~h}$ through real-time supply, and the total water supply volume $Q_{z}$ was observed. The unit water absorption $w$ for each section was calculated using the following formula:

$$
\mathrm{w}=\frac{Q_{\mathrm{z}}}{180\left(\mathrm{P}_{\mathrm{z}} \times \mathrm{L}\right)}
$$

where $P_{z}$ denotes the head height, with units in $\mathrm{m}$; $L$ denotes the section length, with units in $\mathrm{m}$.

3.3.4. Water Pressure Experiment. The water pressure experiment was carried out in the Sangshuping coal mine in the Hancheng mining area (as shown in Figure 1), and 14 directional boreholes were drilled in total: 1-1, 1-2, 1-3, 1-4, 2-1, 22, 2-3, A-1, A-2, A-3, B-1, B-2, C-1, and C-2 (as shown in Figure 6). Directional drilling started from the bottom floor of $11 \#$ coal seam, and the borehole whipstock section was the aquiclude between $11 \#$ coal seam and the Ordovician karst. After reaching 0-20 m from Section 1 of the Fengfeng Formation, borehole drilling shifted to horizontal drilling, with a borehole length of $315-718 \mathrm{~m}$. Casing pipes were set in the whipstock section for stopping water, and the water pressure experiment was carried out on the horizontal section.

The water pressure experiment was carried out after boreholes were formed, and the test section was the drilled horizontal section. A pressure of $1 \mathrm{MPa}$ was applied to the horizontal section, water pressure was maintained for $1 \mathrm{~h}$, and the total water supply volume $Q^{\prime}$ was observed. The unit water absorption $w$ of each section was calculated according to the following formula:

$$
\mathrm{w}=\frac{\mathrm{Q}^{\prime}}{60\left(\mathrm{P}^{\prime} \times \mathrm{L}^{\prime}\right)}
$$

where $P^{\prime}$ denotes the water head height, with units in $\mathrm{m} ; L^{\prime}$ denotes section length, with units in $\mathrm{m}$.

\subsection{Laboratory Experiment}

3.4.1. Experimental Process. Through drilling boreholes, rock specimens were taken from Sections 1 and 2 of the Fengfeng Formation from Hancheng and Chenghe mining areas. Specimens taken from the Hancheng mining area were marlstone, and those from Chenghe mining area were limestone.

Dissolution experiments were carried out on the two types of rock specimens under normal temperature and pressure. The experimental steps were as follows:

(1) Process specimens into complete cuboids of $5 \mathrm{~mm}$ $\times 10 \mathrm{~mm} \times 40 \mathrm{~mm}$ and those broken in the middle of $5 \mathrm{~mm} \times 10 \mathrm{~mm} \times(20 \mathrm{~mm}+20 \mathrm{~mm})$. There are 4 specimens of each lithology and dimension, totaling 16 specimens

(2) Wash the specimens with distilled water, place them in the drying oven and weigh them, and measure their volume

(3) After soaking specimens in distilled water for a period of time at room temperature, carry out the dissolution experiment

(4) Prepare carbonated water (distilled water $+\mathrm{CO}_{2}$ ) and control pH within $5.5 \pm 0.1$

(5) Place the rock specimens in the carbonated water and hang them in the middle of the bottle for carrying out 


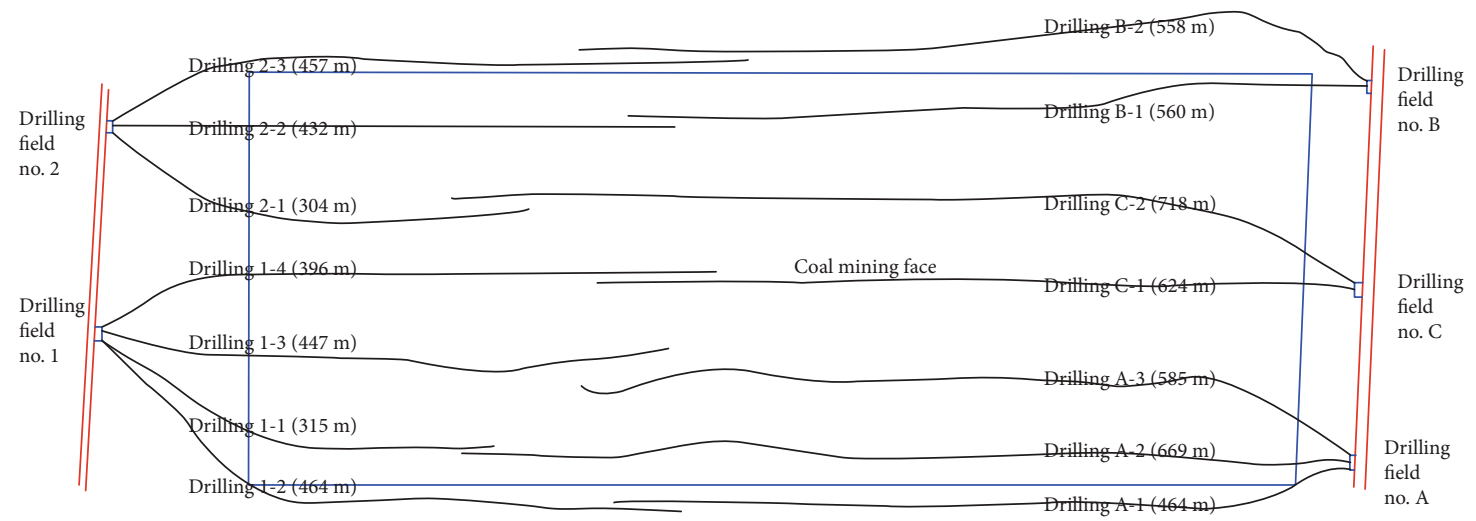

Figure 6: Plane figure of water pressure experiment.

dissolution-erosion experiments. Each dissolution experiment lasts $12 \mathrm{~h}$

(6) Discharge the dissolution solution after the waterrock reaction from the solution pipe and collect the dissolution solution daily. Take $50 \mathrm{~mL}$ of dissolution solution obtained on the $3^{\text {rd }}$ day (the study shows that the dissolution rate tends to be stable after the $2^{\text {nd }}$ day) and measure dissolved $\mathrm{CaCO}_{3}$ and $\mathrm{MgCO}_{3}$

(7) After the experiment, dry the specimens again in the drying oven and weigh them

3.4.2. Calculation of Experimental Results. In the experimental results, the formulas for calculating specific solubility $K_{c v}$, specific dissolution $K_{v}$, and the total physically crushed capacity $K_{n}$ are as follows:

(1) Specific solubility:

$$
K_{c v}=\frac{\left(C_{1}+C_{2}\right) / V}{\left(C_{1}{ }^{\prime}+C_{2}{ }^{\prime}\right) / V^{\prime}}
$$

(2) Specific dissolution:

$$
K_{v}=\frac{\left(m_{0}-m_{1}\right) / V}{\left(m_{0}^{\prime}-m_{1}^{\prime}\right) / V^{\prime}}
$$

(3) Physically crushed capacity:

$$
K_{n}=\left[\left(m_{0}-m_{1}\right)-\left(C_{1}+C_{2}\right)\right]
$$

where $C_{1}$ denotes the dissolved quantity of $\mathrm{CaCO}_{3}$ in specimens, with units in $\mathrm{mg} ; C_{1}{ }^{\prime}$ denotes the mean dissolved quantity of $\mathrm{CaCO}_{3}$ in standard specimens, with units in mg; $C_{2}$ denotes the dissolved quantity of $\mathrm{MgCO}_{3}$ in specimens, with units in $\mathrm{mg} ; C_{2}{ }^{\prime}$ denotes the mean dissolved quantity of $\mathrm{MgCO}_{3}$ in standard specimens, with units in $\mathrm{mg} ; m_{0}$ denotes the specimen mass before dissolution, with units in $\mathrm{mg} ; m_{1}$ denotes the specimen mass after dissolution, with units in $\mathrm{mg} ; m_{0}{ }^{\prime}$ denotes the mean mass of standard specimens before dissolution, with units in mg; $m_{1}{ }^{\prime}$ denotes the mean mass of standard specimens after dissolution, with units in $\mathrm{mg} ; m_{s}$ denotes the dissolved quantity of specimens; $V$ denotes the volume of specimens, with units in $\mathrm{cm}^{3}$; and $V^{\prime}$ denotes the mean volume of standard specimens, with units in $\mathrm{cm}^{3}$.

\section{Results and Discussion}

4.1. Results of the Water Pumping Experiment and Analysis. $Q-S$ curves were drawn according to the water pumping experiment results, which showed that all curves for the eight boreholes were approximately linear (as shown in Figure 7). The permeability coefficient was calculated according to the formula for steady flow of a well with complete confined water, and the pumping capacity at the drawdown of $10 \mathrm{~m}$ was taken from the Q-S curve or the water-bearing coefficient q. The results are shown in Figure 8. As can be seen, the permeability coefficient of the aquifer in the water pumping experiment ranged from 0.245 to $12.21 \mathrm{~m} / \mathrm{d}$, and $q$ ranged from 0.14 to $2.46 \mathrm{~L} / \mathrm{s} \cdot \mathrm{m}$. The results indicate that the Ordovician karst top in the deep part of the Dongjiahe coal mine in the Chenghe mining area had strong heterogeneity and the aquifer had good recharging capability. During the water pumping experiment on the S4 borehole, the water level in the borehole decreased from $+355 \mathrm{~m}$ to $+321 \mathrm{~m}$, and after keeping the water level stable for 10 hours, the karst water level in the main inclined shaft $36 \mathrm{~m}$ away from the borehole was still $+355 \mathrm{~m}$, indicating that the water pumping experiment provided hydrological information around one point, whereas the regional geological conditions were very complicated and could not be identified through the water pumping test.

4.2. Results of the Water Drainage Experiment and Analysis. After drainage holes were closed, the time $t$ for water level recovery in each observation hole was different. According to $W$, the distance between observation holes and drainage holes, the hydraulic transmission velocity along different directions as calculated through $V=W / t$, and the results are shown in Figure 9. In combination with Figure 5, it can be found that there were significant differences between the 


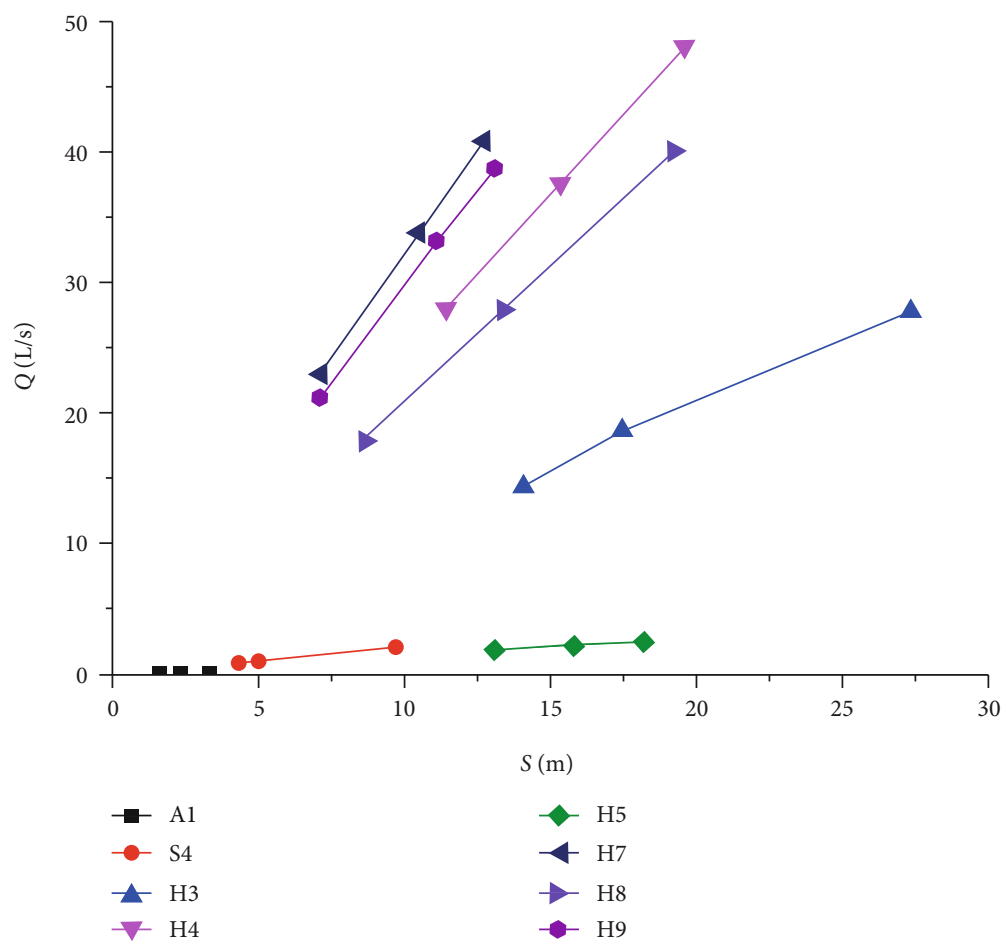

FIgURE 7: Q-S curve of water pumping experiment.

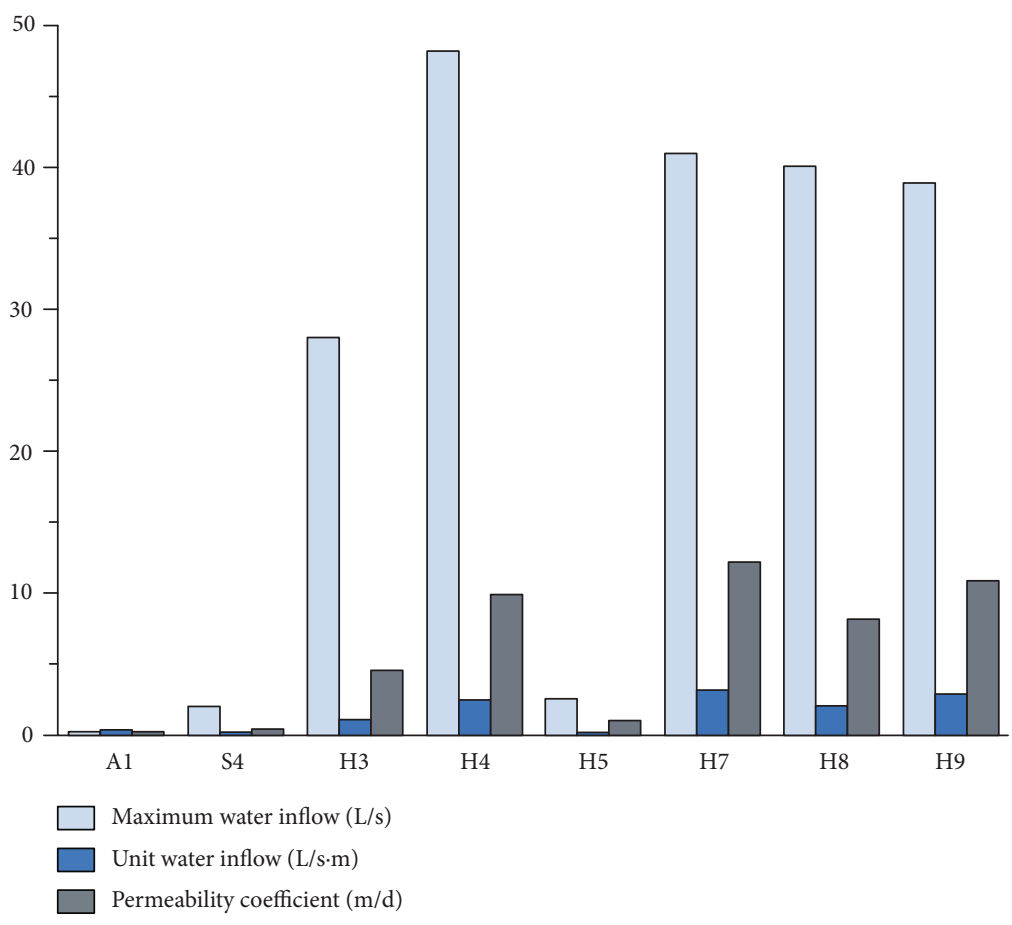

FIGURE 8: Results of water pumping experiment.

hydrological characteristics of the top of deep Ordovician karst strata in the Quanjiahe coal mine in the Chenghe mining area, and the hydraulic transmission velocities along corresponding six directions of observation holes ranged from 49.7 to $520.9 \mathrm{~m} / \mathrm{min}$. In addition, according to previous monographic studies, the F2 fault can transmit water while the F1 fault cannot. The hydraulic transmission speed in the direction perpendicular to the water-conducting fault was the highest, speed in the direction perpendicular to the nonconducting fault was the lowest, and speed in other directions was in between these two. This indicated that structures played a significant role in controlling the 

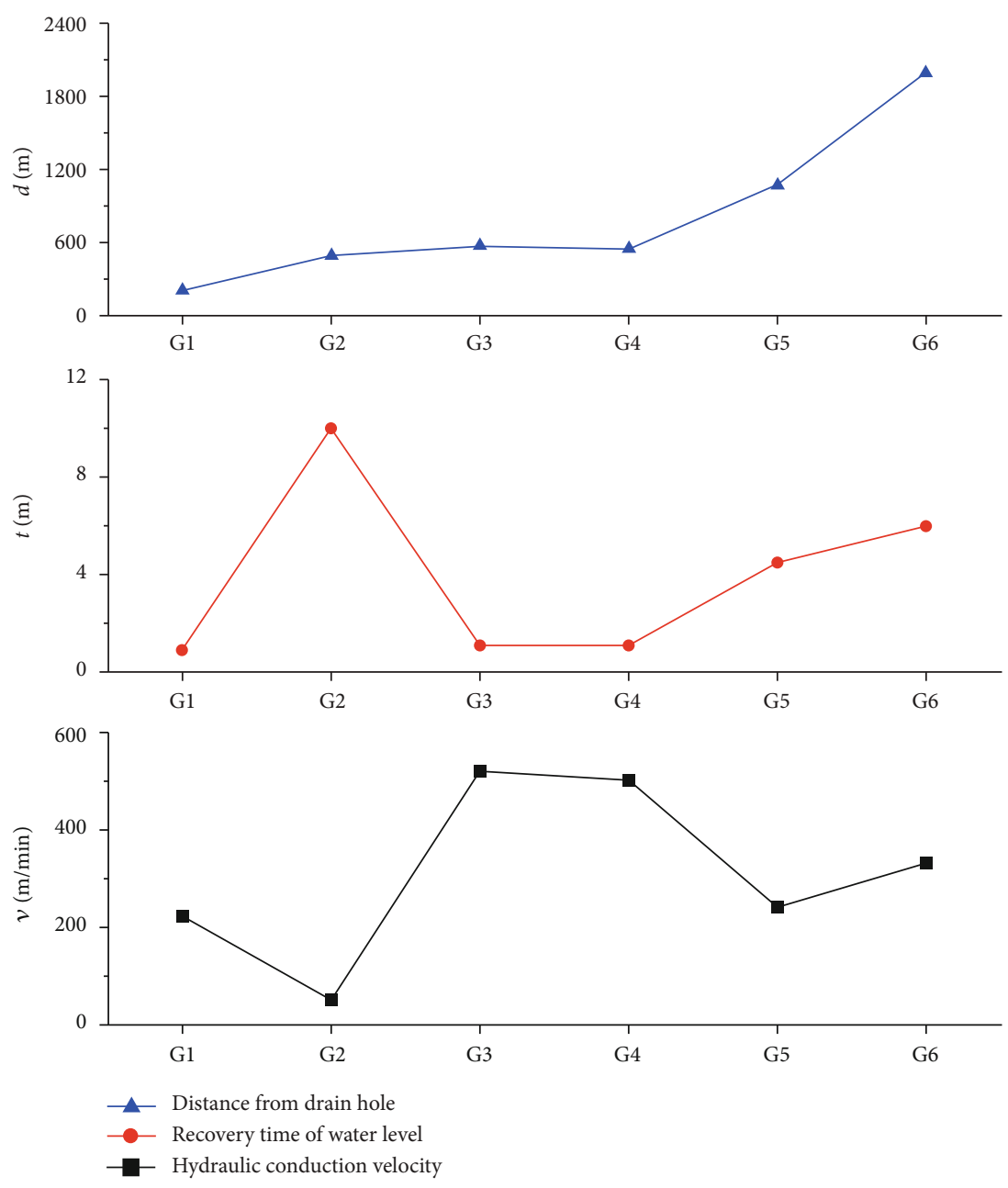

FIGURE 9: Results of water drainage experiment.

hydrological characteristics of karst. In addition, according to the simple analysis of water quality in Figure 10, the content of erosive $\mathrm{CO}_{2}$ near the conducting fault increased, whereas the mineralization around the nonconducting fault was high, which also revealed the significant effects of structures on karst development.

\subsection{Results of the Water Injecting Experiment and Analysis}

(1) The first experimental section: in the first experimental section, bauxite mudstone played a dominant role, along with sandy mudstone. They were mostly aquiclude. The unit water absorption of the section ranged from 0 to $0.0009 \mathrm{~L} / \mathrm{min} . \mathrm{m} . \mathrm{m}$, mostly concentrated in the range of $0.0001-0.0009 \mathrm{~L} / \mathrm{min} . \mathrm{m} . \mathrm{m}$ and accounting for $47 \%$ of the total absorption capacity. It can be seen from the data on unit water absorption that in the experimental area, the region from the 11\# coal seam to top surface of Ordovician karst was integral aquiclude.

(2) The second experimental section: in the second experimental section, marlstone played a dominant role, with breccia limestone, argillaceous limestone, dolo- mitic limestone, limestone, and marlstone, alternating with each other. The unit water absorption for the second water-injected section ranged from 0 to $0.001 \mathrm{~L} / \mathrm{min} . \mathrm{m} . \mathrm{m}$, mostly in the range of 0.0001 $0.0005 \mathrm{~L} / \mathrm{min} . \mathrm{m} . \mathrm{m}$ and accounting for $53 \%$ of the total quantity. It can be seen from the unit water absorption that in the experimental area, the region $20 \mathrm{~m}$ below the top surface of Ordovician karst belonged to a relative aquiclude.

(3) The third experimental section: the lithology of the third experimental section was similar to that of the second and was also dominated by marlstone, associated with alternating breccia limestone, argillaceous limestone, dolomitic limestone, limestone, and marlstone. The unit water absorption for the third experimental section ranged from 0.0000311 to 0.2 $\mathrm{L} / \mathrm{min}$.m.m. The region from the exposed place of borehole injection to $30 \mathrm{~m}$ below the top surface of Ordovician karst was relative aquiclude, but there was a certain amount of water in some parts.

(4) The fourth experimental section: the lithology of the fourth experimental section is similar to that of the 

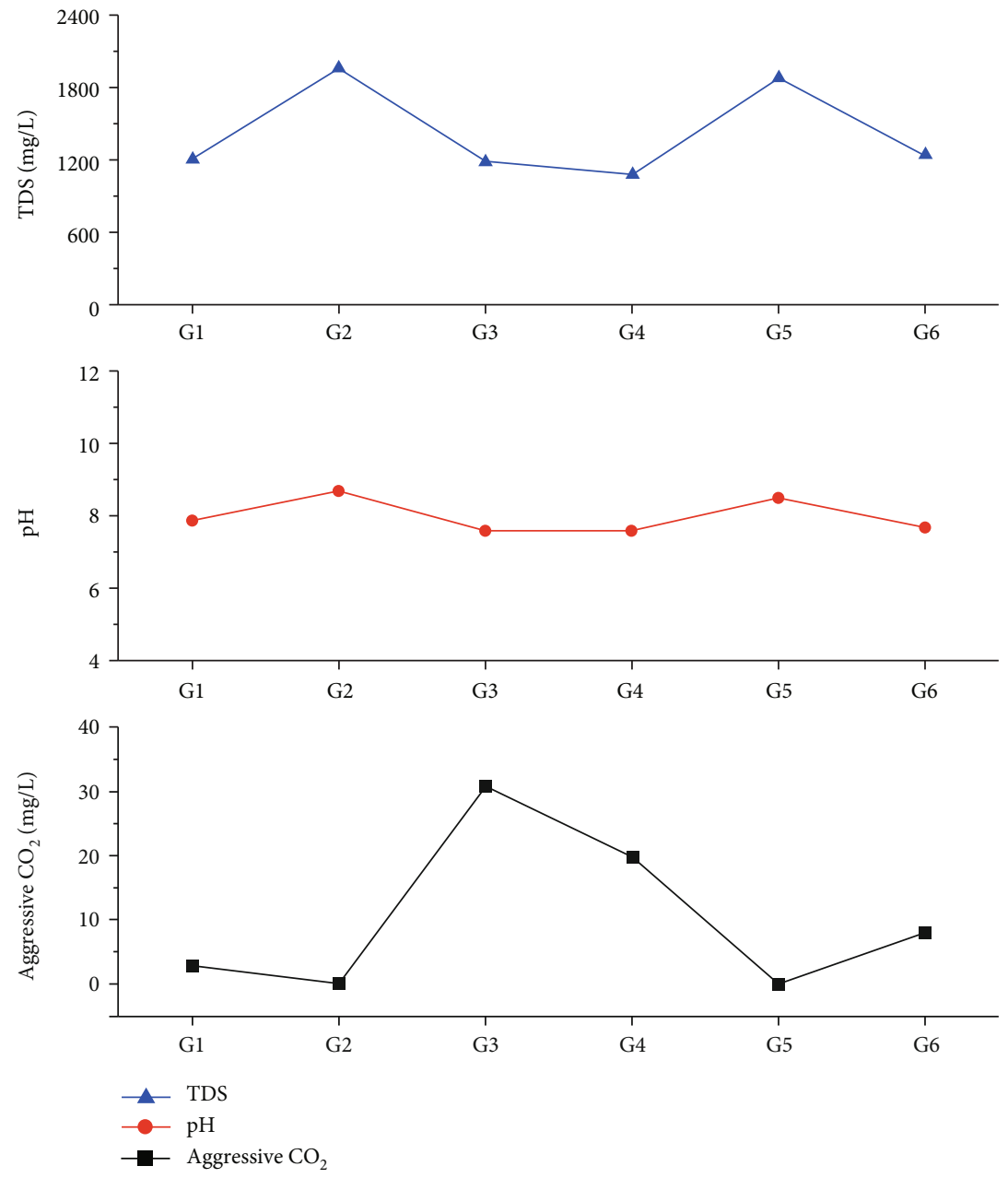

FigURE 10: Water quality test results of observation holes.

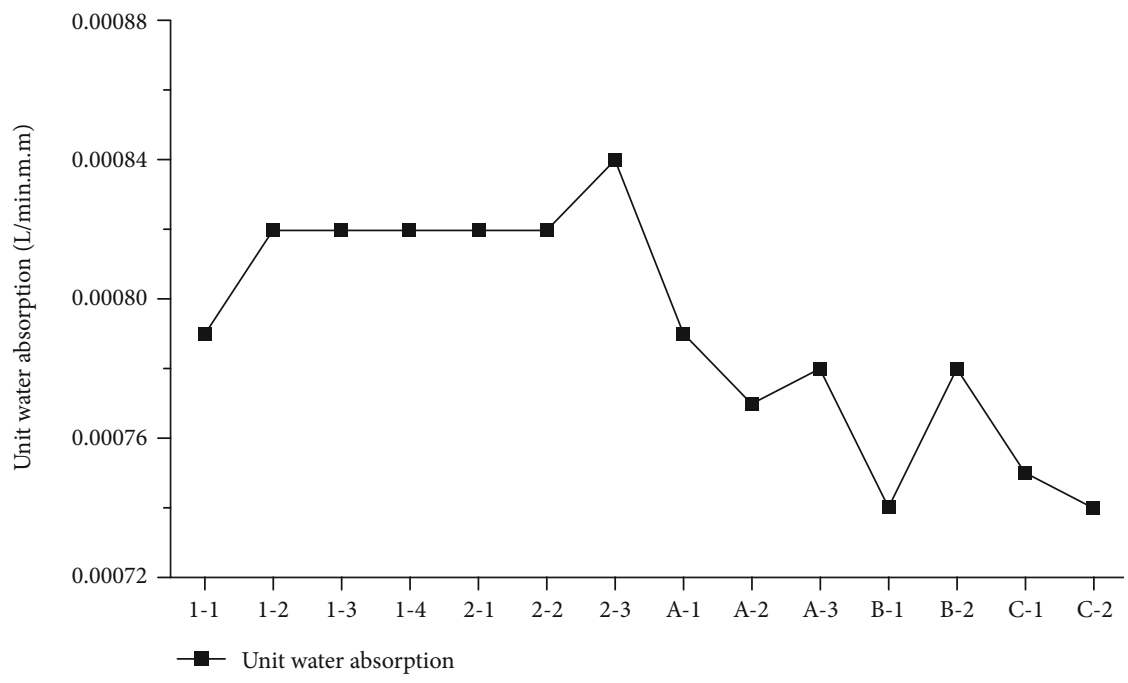

Figure 11: Results of water pressure experiment.

third, also dominated by marlstone, with alternating breccia limestone, argillaceous limestone, dolomitic limestone, limestone, and marlstone. The unit water absorption ranged from 0.0001 to $0.2 \mathrm{~L} / \mathrm{min} . \mathrm{m} . \mathrm{m}$. The region in the range of Section 1 of the Fengfeng Formation from the water injecting borehole to the 
TABLE 1: Comparative analysis of in situ experiment results and qualitative conclusions.

\begin{tabular}{|c|c|c|c|c|}
\hline Qualitative conclusions & $\begin{array}{c}\text { Results of water pumping } \\
\text { experiment }\end{array}$ & $\begin{array}{c}\text { Results of water } \\
\text { drainage experiment }\end{array}$ & $\begin{array}{c}\text { Results of water injecting } \\
\text { experiment }\end{array}$ & $\begin{array}{c}\text { Results of water } \\
\text { pressure } \\
\text { experiment }\end{array}$ \\
\hline $\begin{array}{l}\text { There are many times of } \\
\text { water inrush in Chenghe } \\
\text { mining area. }\end{array}$ & $\begin{array}{l}\text { The permeability coefficient of } \\
\text { the aquifer ranged from } 0.245 \\
\text { to } 12.21 \mathrm{~m} / \mathrm{d} .\end{array}$ & & & \\
\hline $\begin{array}{l}\text { There are few times } \\
\text { of water inrush in } \\
\text { Hancheng mining area. }\end{array}$ & & & $\begin{array}{c}\text { The unit water absorption } \\
\text { measured by second water } \\
\text { injecting experiment was } \\
0-0.001 \mathrm{~L} / \mathrm{min} . \mathrm{m} . \mathrm{m} .\end{array}$ & $\begin{array}{c}\text { The unit water } \\
\text { absorption was } \\
0.00074-0.00084 \\
\text { L/min.m.m. }\end{array}$ \\
\hline $\begin{array}{l}\text { The flow of water inrush } \\
\text { in Chenghe mining area is } \\
\text { large. }\end{array}$ & & $\begin{array}{l}\text { The hydraulic } \\
\text { transmission speed } \\
\text { of the aquifer is } \\
49.7-520.9 \mathrm{~m} / \mathrm{min} \text {. }\end{array}$ & & \\
\hline $\begin{array}{l}\text { The water inrush is } \\
\text { hidden in Hancheng } \\
\text { mining area. }\end{array}$ & & & $\begin{array}{l}\text { The unit water absorption } \\
\text { measured by the third water } \\
\text { injecting experiment was } \\
0.0000311-0.2 \mathrm{~L} / \mathrm{min} . \mathrm{m} . \mathrm{m} \text {. }\end{array}$ & \\
\hline
\end{tabular}

top surface of Ordovician karst belonged to the relative aquiclude, but there was a certain amount of water in some local areas.

The water injecting experiment demonstrated that in Section 1 of the Fengfeng Formation in the Hancheng mining area, karst development was poor, but some regions had water-containing characteristics and along the vertical direction, some changes occurred. There was no significant water content in the range of $20 \mathrm{~m}$ below the top surface of Ordovician karst, which were fully used as aquiclude.

4.4. Results of the Water Pressure Experiment and Analysis. For the Sangshuping coal mine in the Hancheng mining area, the water pressure experiment was conducted after directional drilling was applied to expose the Ordovician karst top, with results shown in Figure 11. The results show that a karst horizontal plane was not well developed in the top section of Ordovician karst in the Hancheng mining area, demonstrating filling characteristic, i.e., karst with limited development was filled by weathering products.

4.5. Comparative Analysis of In Situ Test Results and Qualitative Conclusions. The qualitative understanding of hydrogeological conditions in Section 2.3 and the quantitative hydrogeological test results in Sections 4.1-4.5 had been compared. The comparison results are shown in Table 1, and the improvement and verification of the relative comparative qualitative conclusions of in situ experiments are as follows:

(1) Qualitative conclusion 1: there are many times of water inrush in the Chenghe mining area. Q-S curves for the eight boreholes were approximately linear, and the permeability coefficient of the aquifer in the water pumping experiment ranged from 0.245 to $12.21 \mathrm{~m} / \mathrm{d}$. The results of in situ experiments verify the qualitative conclusion.
(2) Qualitative conclusion 2: there are few times of water inrush in the Hancheng mining area. The unit water absorption measured by water injecting experiment and water pressure experiment was less than 0.001 $\mathrm{L} / \mathrm{min}$.m.m. The results of in situ experiments verify the qualitative conclusion.

(3) Qualitative conclusion 3: the flow of water inrush in the Chenghe mining area is large. The influence radius of the water pumping experiment is smaller than that of the water drainage experiment, so the correlation between water inrush flow and water drainage experiment results is higher. The water drainage experiment showed that the hydraulic transmission speed of the aquifer is 49.7$520.9 \mathrm{~m} / \mathrm{min}$, which indicates that the Ordovician limestone in the Chenghe mining area had a good hydraulic connection. The qualitative conclusion is further explained by in situ experiments.

(4) Qualitative conclusion 4: water inrush is hidden in the Hancheng mining area. The water pressure experiment and second water injecting experiment showed that water inrush did not occur in the Hancheng mining area under normal conditions. The third water injecting experiment showed that the unit water absorptions in the local area were increased by 2 orders of magnitude. The results show that hidden water inrush may occur in the area of structural development. The qualitative conclusion is further explained by in situ experiments.

4.6. Results of the Dissolution Experiment and Analysis. The results of the dissolution experiment on the two main Ordovician karst top lithologies in the study area are shown in Table 2. It can be seen that the dissolution of marlstone from Section 1 of the Fengfeng Formation was significantly poorer than that of limestone in Section 2. This was because the content of chemical component $\mathrm{CaO}$ in limestone from Section 2 
TABLE 2: Comparison table of dissolution and dissolution of main types of Ordovician karst in the study area.

\begin{tabular}{|c|c|c|c|c|c|}
\hline Rock type (size) & $\begin{array}{l}\text { Total dissolution } \\
\text { amount }(\mathrm{g})\end{array}$ & $\begin{array}{c}\text { Specific } \\
\text { dissolution }\end{array}$ & $\begin{array}{l}\text { Total solubility } \\
\text { amount (g) }\end{array}$ & $\begin{array}{l}\text { Specific } \\
\text { solubility }\end{array}$ & $\begin{array}{l}\text { Physically crushed } \\
\text { capacity (g) }\end{array}$ \\
\hline Whole limestone $(5 \mathrm{~mm} \times 10 \mathrm{~mm} \times 40 \mathrm{~mm})$ & 0.1375 & 0.9543 & 0.1370 & 1.0602 & 0.0005 \\
\hline Whole dolomitic marl $(5 \mathrm{~mm} \times 10 \mathrm{~mm} \times 40 \mathrm{~mm})$ & 0.02890 & 0.24518 & 0.02074 & 0.2228 & 0.00816 \\
\hline Fractured limestone $(5 \mathrm{~mm} \times 10 \mathrm{~mm} \times(20 \mathrm{~mm}+20 \mathrm{~mm}))$ & 0.1473 & 1.0223 & 0.1467 & 1.1353 & 0.0006 \\
\hline $\begin{array}{l}\text { Fractured dolomitic marl } \\
(5 \mathrm{~mm} \times 10 \mathrm{~mm} \times(20 \mathrm{~mm}+20 \mathrm{~mm}))\end{array}$ & 0.03080 & 0.26130 & 0.02262 & 0.2430 & 0.00818 \\
\hline
\end{tabular}

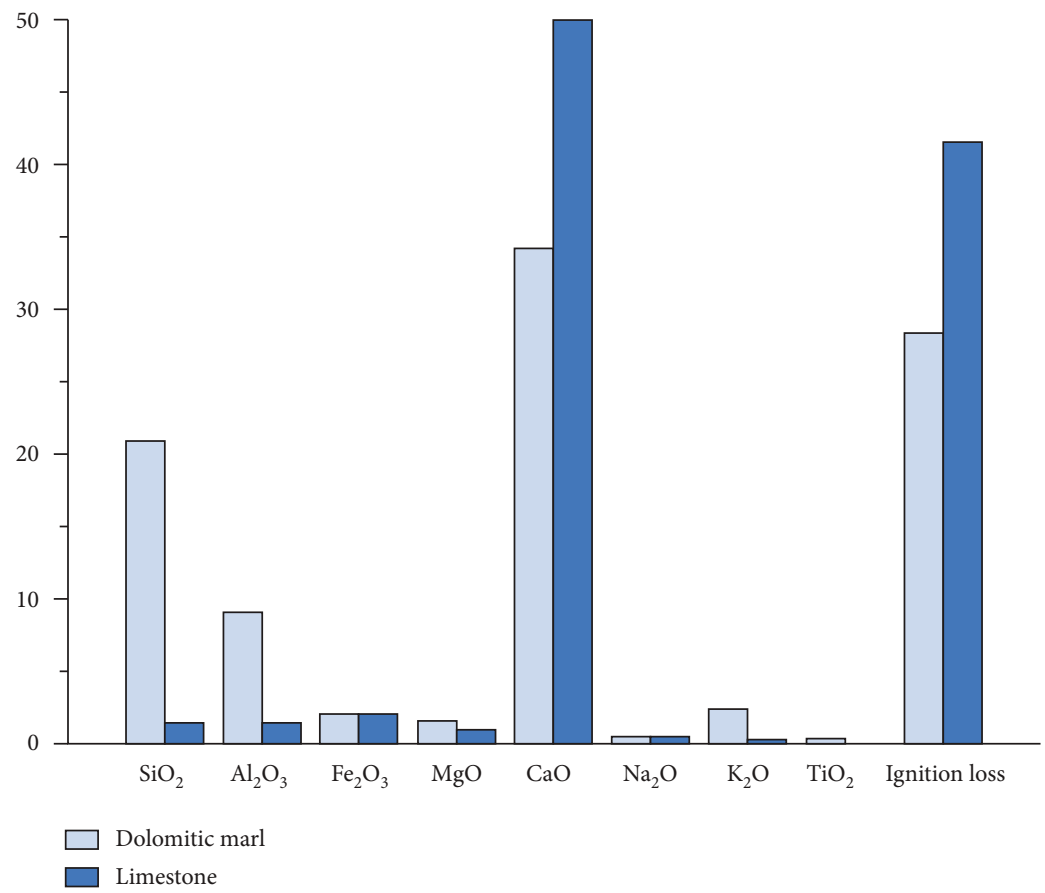

Figure 12: Chemical composition of Ordovician karst.

was significantly higher than that in marlstone from Section 1 (as shown in Figure 12).

\subsection{Analysis of Karst Characteristics from the Ordovician Karst Top}

4.7.1. Characteristics of Karst from the Ordovician Karst Top. A combination of in situ hydrological tests and laboratory dissolution experiments revealed the karst development characteristics of Ordovician karst top, which are summarized as follows:

(1) Heterogeneity. In the study area, karst development was remarkably heterogeneous. Different lithology types in the same region, the same lithology type in different regions, and different depths in the same stratum all showed heterogeneity.

(2) Vertical Zonation. For the Ordovician karst top in the study area, karst in Section 2 of the Fengfeng Formation developed fully on the whole and had strong water yield properties, while that in Section 1 developed in a limited manner with very weak water-bearing properties.
(3) Filling Situations of Partial Regions. Ordovician karst in the Chenghe mining area did not show significant filling properties, whereas the Ordovician karst top in the Hancheng mining area was Section 1 of the Fengfeng Formation with a filling zone that was not rich in water and a thickness of $20-50 \mathrm{~m}$. The filling zone in the top section of Ordovician karst generally developed, but there was no filling zone in the area with developed structure and rock breakage, which often evolved into an area rich in water (for example, in the third section of water injecting experiments, the unit water absorption was $0.0000311-0.2 \mathrm{~L} / \mathrm{min} . \mathrm{m} . \mathrm{m}$; there were large differences between the cases with and without tectonic results).

4.7.2. Analysis of Controlling Factors for Ordovician Karst Top Characteristics. The karst on the Ordovician karst top in the study area had significant development characteristics. Combined with the experimental results, the controlling factors for development were analyzed as follows:

(1) Sedimentation Control. The sedimentation of Ordovician karst was mainly affected by the sedimentary environment during its forming and the change in sedimentary environment in the later stage. 
(1) Effects of sedimentary environment in the earlier stages: in different sedimentary environments, there were various sedimentary strata, such as limestone, dolomite, and marlstone. Different types of rocks had different chemical compositions (Figure 12), resulting in different dissolution resistance (Table 2). Among these, the dissolution of limestone was better than that of marlstone, and through further subdivision, it was related to the purity of carbonate: higher carbonate purity led to better dissolution.

The hydrological characteristics of the Ordovician karst top in different mining areas were significantly affected by lithology. Section 2 of the Fengfeng Formation was dominated by limestone, so its aquifer was rich in water. The results of water pumping and water drainage experiments in the Chenghe mining area verified this conclusion. Section 2 of the Fengfeng Formation was dominated by marlstone, so it was an aquiclude. The water pressure and water injecting experimental results in the Hancheng mining area verified this conclusion. To some extent, the difference determined the differences in hydrogeological characteristics of Ordovician karst in the Hancheng and Chenghe mining areas: Ordovician karst top in the Hancheng mining area (Section 1 of the Fengfeng Formation) was generally an aquiclude; in the Chenghe mining area (Section 2 of the Fengfeng Formation), it was generally an aquifer.

(2) Effects of sedimentary environment in the later stages: according to previous studies in North China, there were obvious planes of unconformity between the Ordovician and Carboniferous, and the upper Ordovician and lower Carboniferous strata were generally absent [37]. In the study area, the large amount of bauxite mudstone between the coal seam and the Ordovician top boundary was the product of such crust uplift and weathering. The sedimentary event in the later stage produced the following effects:

(i) During the post-Ordovician period, the crust in the Hancheng mining area uplifted earlier than that in the Chenghe mining area. As a result, Section 2 of the Fengfeng Formation was generally weathered, and Section 1 remained as the top section. Comparatively, the crust in the Chenghe mining area uplifted later, and large sections of strata of Section 2 were left in the top section of Ordovician karst.

(ii) Due to the existence of planes of unconformity, the partially developed karst in the top section of Ordovician karst in the Hancheng mining area was filled with the weathering products of paleocrust [38], so the filling characteristics of the top section were observed in the Hancheng mining area. Comparatively, in the Chenghe mining area, because the lithology of the top section had stronger dissolution, karst developed exten- sively. Although it was also filled, there was still space filled with water due to dissolution of groundwater activity in the later stage, but there were no filling characteristics overall.

In sum, sedimentation controlled the aquiclude differences of Ordovician karst top in the two mining areas to some extent and showed karst heterogeneity within different areas, zonage at different depths in the same area, and filling properties of top strata sections in some areas.

(2) Tectonic Control

The basic conditions for karst development included soluble rock, sufficient groundwater with dissolution capability, and flow channel of water. The three conditions were controlled by tectonics in varying degrees, so the effect of tectonics on karst development cannot be ignored. The three conditions were analyzed as follows:

(1) Effects of soluble rock development: under the same lithology, when the tectonics developed, the rock was further broken, increasing the contact area between karst and dissolved water, as well as the physical crushing capacity and dissolved quantity. The results of the dissolution experiment indicated that when the specimen surface area increased, its dissolved quantity and physically crushed quantity increased significantly.

(2) Effects of dissolution ability of water: on the one hand, Ordovician karst water in the Chenghe and Hancheng mining areas was recharged by precipitation in karst-exposed areas in the Pubai and Tongchuan mining areas; on the other hand, it was recharged deeply by other surface rivers. Because karst-exposed areas were far away, the amount of erosive $\mathrm{CO}_{2}$ decreased and the dissolution capability decreased significantly. When the fault was a waterconducting fault, the amount of $\mathrm{CO}_{2}$ was significantly supplemented. According to water quality testing in the water drainage experiment, the content of erosive $\mathrm{CO}_{2}$ in water increased significantly near the water-conducting fault (Figure 10).

(3) Effects of runoff channels: the direction, quantity, and scale of runoff channels can directly affect the dissolution degree of karst water and surrounding rock, as well as the degree of water erosion. The development of water-conducting structures provided good channels for runoff in karst. For example, in the water drainage experiment, the hydraulic transmission speed of water-conducting F2 fault was significantly higher, which provided good channels for karst development. Comparatively, due to its water-resisting property, the F1 fault hindered the flow of karst water and karst development was relatively weak.

In summary, karst development was controlled by sedimentation and tectonic development. Such local controlling factors cannot be ignored for security reasons, so it is necessary to detect Ordovician karst top before each coal face is 
mined to prevent water inrush accidents from occurring in areas with abnormal structure.

\subsection{Application of Threat Assessment of Ordovician Confined Water to Coal Mines in the Study Area}

4.8.1. The Water Inrush Coefficient Theory. The water inrush coefficient theory has changed many times since its original form (Formula (6)). More factors have been considered, such as the damaged depth of the coal mining floor (Formula (7)) and water yield properties ${ }^{[38]}$. However, when applied under different mining and geological conditions, the water inrush coefficient theory still has some problems. For example, the Ts- $q$ method proposed by Li et al. ${ }^{[38]}$ was applied in the study area and demonstrated a larger error when applied in the study area in this paper. The aquiclude thickness $M$ in the study area was about $20 \mathrm{~m}$, but water inrush occurred less in the Hancheng mining area. However, in the literature [38], it is believed that under such circumstances, water inrush should have occurred more often.

$$
\text { Ts }=\frac{P}{M} \text {. }
$$

In Formula (6), Ts denotes the water inrush coefficient, with units in $\mathrm{MPa} / \mathrm{m} ; P$ denotes the pressure of Ordovician karst acting on the aquiclude, with units in $\mathrm{MPa}$; and $M$ denotes the distance from the interface of the Ordovician karst top to the mining coal seam, with units in $\mathrm{m}$. When $\mathrm{Ts} \geq \mathrm{Ts}_{0}$, water inrush from the bottom floor is likely to occur on the mining face; otherwise, water inrush from the bottom floor will occur with a lower probability. $\mathrm{Ts}_{0}$ denotes the critical water inrush coefficient obtained from empirical value statistics, with units in $\mathrm{MPa} / \mathrm{m}$.

$$
\mathrm{Ts}=\frac{P}{M-\mathrm{cp}} .
$$

In Formula (7), cp denotes the depth of damage to the bottom floor, with units in $\mathrm{m}$.

\subsubsection{Classified Application of the Water Inrush Coefficient Theory}

(1) Classification of Water Inrush Risk Evaluation Based on Karst Hydrogeological Condition. According to the analysis results from Section 4.7, when coal mining was carried out on the Ordovician karst aquifer in the study area, karst hydrogeological conditions were somewhat different. The differences were reflected by the water inrush coefficient theory from two aspects. On the one hand, due to the existence of the filling zone on Ordovician karst top, the identification of the aquiclude thickness $M$ was different (it was no longer the distance from the Ordovician karst to the coal seam, possibly with the aquiclude thickness in the filling zone); on the other hand, the three parameters $M, \mathrm{Ts}_{0}$, and $\mathrm{cp}$ were different in areas with and without structure development. According to the differences in both aspects, the geological conditions for mining in the study area were divided into three types.
(1) The Ordovician karst top had neither filling nor significant structure (type 1): this type was mainly concentrated in the Chenghe mining area. Because Section 2 of the Fengfeng Formation continuously had a large area, the Ordovician karst top was a stratum rich in water. For this type, Formula (7) should be selected for calculating the water inrush coefficient.

(2) The Ordovician karst top had filling but no significant structure (type 2): this type was mainly concentrated in the Hancheng mining area. Because Section 2 of Fengfeng Formation wedges out, the Ordovician karst top was a stratum poor in water, which can be regarded as a relative aquiclude, and $20 \mathrm{~m}$ was the thickness for safety. For this type, Formula (8) was selected for calculating the water inrush coefficient

$$
\mathrm{Ts}=\frac{P}{M+20-\mathrm{cp}} .
$$

(3) The Ordovician karst top had significantly developed tectonics (type 3): this type was sporadically distributed in the Hancheng and Chenghe mining areas. Due to the tectonic effects, this type of top section had a thinner aquiclude, increased damage depth to the bottom floor of the coal seam, and lower critical water inrush coefficient. In addition, this type was distributed in a random manner, with high crypticity and is difficult to explore, so monographic studies are needed. The formula for evaluation was obtained from monographic studies. Previous water inrush accidents have shown that this type presents a significant hazard, and accident prevention should be emphasized.

(2) Application of Classified Evaluation. The evaluation methods for types 1 and 2 were applied for the Chenghe and Hancheng mining areas and successfully predicted the water inrush risk from the bottom floor of seven coal faces. Results are shown in Table 3. The water inrush coefficient for the Chenghe mining area was generally higher than the critical value, so coal mining was carried out safely after grouting reinforcement was conducted on the bottom floor. On the other hand, the water inrush coefficient for the Hancheng mining area was generally lower than the critical value, so coal mining was directly carried out safely without conducting grouting reinforcement on the bottom floor. According to prior results from geophysical prospecting and drilling, coal face 22508 in the Dongjiahe coal mine of the Chenghe mining area belonged to the type with significantly developed structure (type 3), suggesting that water inrush accidents may occur with high probability. Therefore, in areas with structure, coal resources from coal face 22508 could be mined safely and successfully after grouting reinforcement was conducted on the bottom floor. 
TABLE 3: Risk prediction of water inrush in coal working faces based on classification of geological conditions.

\begin{tabular}{lcccccc}
\hline No. & Mining area & Coal mine & Working face & Evaluation type & Evaluation result & Actual mining process \\
\hline 1 & Chenghe & Chengheerkuang & 24508 & Type 1 & Water inrush & Grouting and safe coal mining \\
2 & Chenghe & Chengheerkuang & 24506 & Type 1 & Water inrush & Grouting and safe coal mining \\
3 & Chenghe & Dongjiahe & 22507 & Type 1 & Water inrush & Grouting and safe coal mining \\
4 & Chenghe & Dongjiahe & 22506 & Type 1 & Water inrush & Grouting and safe coal mining \\
5 & Chenghe & Wangcunxiejing & 5206 & Type 1 & Nonwater inrush & Safe coal mining \\
6 & Chenghe & Dongjiahe & 22508 & Type 3 & Water inrush & Grouting and safe coal mining \\
7 & Hancheng & Sangshuping & 3105 & Type 2 & Nonwater inrush & Safe coal mining \\
8 & Hancheng & Magouqu & 1100 & Type 2 & Nonwater inrush & Safe coal mining \\
\hline
\end{tabular}

TABLE 4: The depth of floor failure and main control factors in the study area.

\begin{tabular}{lcccc}
\hline No. & Working face & $L_{d}(\mathrm{~m})$ & $D(\mathrm{~m})$ & $\mathrm{cp}(\mathrm{m})$ \\
\hline 1 & 22506 & 96.0 & 0.7 & 11.8 \\
2 & 22507 & 114.0 & 0.7 & 12.0 \\
3 & 24504 & 140.0 & 0.1 & 13.5 \\
4 & 24508 & 60.0 & 0.8 & 11.5 \\
5 & 5208 & 150.0 & 0.6 & 12.0 \\
6 & 5206 & 150.0 & 0.9 & 11.5 \\
7 & 14503 & 136.4 & 0.5 & 13.6 \\
8 & 13506 & 125.0 & 0.7 & 12.1 \\
\hline
\end{tabular}

It should be noted that under normal structural development in the study area, the damaged depth of the bottom floor of coal seam cp could be obtained by multivariate nonlinear fitting based on numerical simulation and field measurement results (Table 4), following Formula (9). However, for actual measurement of areas with significant tectonic development, twice the number of monographic studies is needed compared to areas with normal structure.

$$
\mathrm{cp}=10.3963+0.7206 \ln L_{d}-2.4618 D,
$$

where $L_{d}$ denotes the inclined length of the coal face, with units in $\mathrm{m}$, and $D$ denotes the combination lithology coefficient of the coal face bottom floor, which is a dimensionless percentage of hard rock on the bottom floor.

In summary, risk prediction of water inrush from the bottom floor for coal mining based on karst hydrogeological characteristics guarantees the mining of coal resources in the study area.

\section{Conclusions}

The hydrogeological conditions of Ordovician limestone top section had been explored and analyzed. Based on the recognition of hydrogeological characteristics, the water inrush risk classification evaluation system had been proposed. The findings of this study can be summarized as follows:

(1) The hydrogeological characteristics of the Ordovician karst top in the study areas included heterogeneity, vertical zonation, and partially filling properties
(2) Karst development was controlled by two factors: sedimentation and tectonism

(3) Based on the hydrological characteristics of Ordovician karst top in the study area, the evaluation of water inrush risk in coal mining under pressure was divided into three types

(4) Formula (7) and Formula (8) should be used to evaluate the risk of water inrush of types 1 and 2 . The condition of type 3 is changeable and needs special research

(5) The three types were used to successfully predict the risk of water inrush occurring on eight coal faces

\section{Data Availability}

The data used to support the findings of this study are available from the corresponding author upon request.

\section{Conflicts of Interest}

The authors declare that they have no conflicts of interest.

\section{Acknowledgments}

This paper was funded by the Fund of Liupanshui Normal University High Level Talent Research Start-Up (LPSSYKYJJ201702), by the Guizhou Coal Green Development 2011 Collaborative Innovation Center ([2016] 02), by the Guizhou Provincial Education Department Fund (QianjiaoheKYzi [2018]376, QianjiaoheKYzi [2018]386, QianjiaoheKYzi [2017]275, and QianjiaoheKYzi [2018]029), by the Key Disciplines Fund of Liupanshui Normal University (LPSSYZDXK201802), by the Liupanshui Key Laboratory Project (52020-2019-05-03), by the Fund of Liupanshui Normal University (LPSSY201806), by the Fund of Guizhou Science and Technology Department (Qiankehejichu[2019]1291, Qiankehejichu[2019]1293, QiankeheLHzi[2015]7607, and Qiankehepingtairencai[2019]5620), by the National Natural Science Foundation of China (41702270), and by the Science and Technology Innovation Team of Liupanshui Normal University (LPSSYKJTD201902). 


\section{References}

[1] W. T. Wang, Y. P. Liang, Z. H. Wang, and C. H. Zhao, "Characteristics of climate change in northern China and its effect on groundwater in karst areas," Hydrogeology \& Engineering Geology, vol. 39, no. 6, pp. 6-10+28, 2012.

[2] Y. H. Hao, W. Wang, and G. Q. Wang, "Effects of climate change and human activities on the karstic springs in northern China: a case study of the Liulin Springs," Acta Geologica Sinica, vol. 83, no. 1, pp. 139-144, 2009.

[3] D. Ma, H. Bai, and Y. Wang, "Mechanical behavior of a coal seam penetrated by a karst collapse pillar: mining-induced groundwater inrush risk," Natural Hazards, vol. 75, no. 3, pp. 2137-2151, 2015.

[4] D. Ma and H. Bai, "Groundwater inflow prediction model of karst collapse pillar: a case study for mining-induced groundwater inrush risk," Natural Hazards, vol. 76, no. 2, pp. 13191334, 2015.

[5] Q. Wu, X. Guo, J. Shen, S. Xu, S. Liu, and Y. Zeng, "Risk assessment of water inrush from aquifers underlying the Gushuyuan coal mine, China," Mine Water and the Environment, vol. 36, no. 1, pp. 96-103, 2017.

[6] W. J. Sun, W. F. Zhou, and J. Jiao, "Hydrogeological classification and water inrush accidents in China's coal mines," Mine Water and the Environment, vol. 35, no. 2, pp. 214-220, 2016.

[7] W. Daher, S. Pistre, A. Kneppers, M. Bakalowicz, and W. Najem, "Karst and artificial recharge: Theoretical and practical problems: A preliminary approach to artificial recharge assessment," Journal of Hydrology, vol. 408, no. 3-4, pp. 189202, 2011.

[8] K. Li, "Study on hydrogeologic conditions of Ordovician limestone aquifer in medium deep section of Yanzhou coal field," Coal Science and Technology, vol. 44, no. 4, pp. 146149, 2016.

[9] Y. Y. Bian, D. Zhao, and Y. Han, "Hydrochemical characteristics and formation mechanism of Ordovician limestone groundwater in the Yanzhou coalfield," Acta Geologica Sinica, vol. 38, no. 2, pp. 236-242, 2017.

[10] Y. Jiang, Y. Wu, C. Groves, D. Yuan, and P. Kambesis, "Natural and anthropogenic factors affecting the groundwater quality in the Nandong karst underground river system in Yunan, China," Journal of Contaminant Hydrology, vol. 109, no. 1-4, pp. 49-61, 2009.

[11] W. Qiao, W. Li, and X. Zhang, "Characteristic of water chemistry and hydrodynamics of deep karst and its influence on deep coal mining," Arabian Journal of Geosciences, vol. 7, no. 4, pp. 1261-1275, 2014.

[12] Q. Wu, D. Zhao, Y. Wang, J. Shen, W. Mu, and H. Liu, "Method for assessing coal-floor water-inrush risk based on the variable-weight model and unascertained measure theory," Hydrogeology Journal, vol. 25, no. 10, pp. 2089-2103, 2017.

[13] X. Qiao, G. Li, M. Li et al., "Influence of coal mining on regional karst groundwater system: a case study in west mountain area of Taiyuan City, northern China," Environmental Earth Sciences, vol. 64, no. 6, pp. 1525-1535, 2011.

[14] G. Li and W. Zhou, "Impact of karst water on coal mining in North China," Environmental Geology, vol. 49, no. 3, pp. 449-457, 2006.

[15] Q. Wu and M. Wang, "Characterization of water bursting and discharge into underground mines with multilayered groundwater flow systems in the North China coal basin," Hydrogeology Journal, vol. 14, no. 6, pp. 882-893, 2006.
[16] J. Wu, P. Li, and H. Qian, "Hydrochemical characterization of drinking groundwater with special reference to fluoride in an arid area of China and the control of aquifer leakage on its concentrations," Environmental Earth Sciences, vol. 73, no. 12, pp. 8575-8588, 2015.

[17] Q. Wu, S. Fan, W. Zhou, and S. Liu, "Application of the analytic hierarchy process to assessment of water inrush: a case study for the no. 17 coal seam in the Sanhejian coal mine, China," Mine Water and the Environment, vol. 32, no. 3, pp. 229-238, 2013.

[18] Y. Zhang, S. Cao, N. Zhang, and C. Zhao, "The application of short-wall block backfill mining to preserve surface water resources in northwest China," Journal of Cleaner Production, vol. 261, article 121232, 2020.

[19] H. Yan, J. Zhang, N. Zhou, and M. Li, "Application of hybrid artificial intelligence model to predict coal strength alteration during $\mathrm{CO}_{2}$ geological sequestration in coal seams," Science of The Total Environment, vol. 711, article 135029, 2020.

[20] H. Yan, J. Zhang, S. S. Rahman, N. Zhou, and Y. Suo, "Predicting permeability changes with injecting $\mathrm{CO}_{2}$ in coal seams during $\mathrm{CO}_{2}$ geological sequestration: a comparative study among six SVM-based hybrid models," Science of The Total Environment, vol. 705, article 135941, 2020.

[21] Q. Wu, Y. Liu, D. Liu, and W. Zhou, "Prediction of floor water inrush: the application of GIS-based AHP vulnerable index method to Donghuantuo coal mine, China," Rock Mechanics and Rock Engineering, vol. 44, no. 5, pp. 591-600, 2011.

[22] Q. Wu, Y. Liu, X. Wu, S. Liu, W. Sun, and Y. Zeng, “Assessment of groundwater inrush from underlying aquifers in Tunbai coal mine, Shanxi province, China," Environmental Earth Sciences, vol. 75, no. 9, pp. 1-13, 2016.

[23] Q. Wu, Y. Liu, W. Zhou et al., "Evaluation of water inrush vulnerability from aquifers overlying coal seams in the Menkeqing coal mine, China," Mine Water and the Environment, vol. 34, no. 3, pp. 258-269, 2015.

[24] Q. Wu and W. Zhou, "Prediction of groundwater inrush into coal mines from aquifers underlying the coal seams in China: vulnerability index method and its construction," Environmental Geology, vol. 56, no. 2, pp. 245-254, 2008.

[25] W. Qiao, W. Li, X. Zhang et al., "Prediction of floor water disasters based on fractal analysis of geologic structure and vulnerability index method for deep coal mining in the Yanzhou mining area," Geomatics, Natural Hazards and Risk, vol. 10, no. 1, pp. 1306-1326, 2019.

[26] B. Boughriba, A. Barkaoui, Y. Zarhloule, Z. Lahmer, B. E. Houadi, and M. Verdoya, "Groundwater vulnerability and risk mapping of the Angad transboundary aquifer using DRASTIC index method in GIS environment," Arabian Journal of Geosciences, vol. 3, no. 2, pp. 207-220, 2010.

[27] L. Ribeiro, J. C. Domingue, and L. Dominguez-Granda, "Assessment of groundwater vulnerability in the Daule aquifer, Ecuador, using the susceptibility index method," Science of the Total Environment, vol. 574, no. 1, pp. 1674-1683, 2017.

[28] W. Chen, H. Li, E. K. Hou et al., "GIS-based groundwater potential analysis using novel ensemble weights-of-evidence with logistic regression and functional tree models," Science of the Total Environment, vol. 634, no. 1, pp. 853-867, 2018.

[29] D. K. Zhao, Q. Wu, F. P. Cui, H. Xu, Y. F. Zeng, and Y. Z. Du, "Using random forest for the risk assessment of coal-floor water inrush in Panjiayao coal mine, northern China," Hydrogeology Journal, vol. 26, no. 7, pp. 2327-2340, 2018. 
[30] Y. L. Lu and L. G. Wang, "Numerical simulation of mininginduced fracture evolution and water flow in coal seam floor above a confined aquifer," Computers and Geotechnics, vol. 67, pp. 157-171, 2015.

[31] S. C. Zhang, W. J. Guo, Y. Y. Li, W. B. Sun, and D. W. Yin, "Experimental simulation of fault water inrush channel evolution in a coal mine floor," Mine Water and the Environment, vol. 36, no. 3, pp. 443-451, 2017.

[32] H. Yin, J. Wei, L. Lefticariu, J. Guo, D. Xie, and Z. Li, "Numerical simulation of water flow from the coal seam floor in a deep longwall mine in China," Mine Water and the Environment, vol. 35, no. 2, pp. 243-252, 2016.

[33] B. Yao, H. Bai, and B. Zhang, "Numerical simulation on the risk of roof water inrush in Wuyang coal mine," International Journal of Mining Science and Technology, vol. 22, no. 2, pp. 273-277, 2012.

[34] SAWSC, "Coal mine water prevention and control regulations," China Coal Industry Public House, pp. 84-85, 2009.

[35] Q. Wu, Z. L. Zhang, and J. F. Ma, "A new practical methodology of the coal floor water bursting evaluating I: the master controlling index system construction," Journal of China Coal Society, vol. 32, no. 1, pp. 245-254, 2007.

[36] W. Qiao, W. P. Li, and C. X. Zhao, "Water inrush coefficientunit inflow method for water inrush evaluation of coal mine floor," Chinese Journal of Rock Mechanics and Engineering, vol. 28, no. 12, pp. 2466-2474, 2009.

[37] W. P. Li, Y. Liu, and W. Qiao, “An improved vulnerability assessment model for floor water bursting from a confined aquifer based on the water inrush coefficient method," Mine Water and the Environment, vol. 37, no. 1, pp. 196-204, 2018.

[38] W. P. Li, W. Qiao, X. Q. Li, and R. H. Su, "Characteristics of water disaster, evaluation methods and exploration direction for controlling groundwater in deep mining," Journal of China Coal Society, vol. 44, no. 8, pp. 196-204, 2019. 